\title{
Biogenic Sources of Ice Nucleation Particles at the High Arctic Site Villum Research Station
}

\section{Supplementary Information}

\section{Tina Šantl-Temkivi,2,3,4*, Robert Lange ${ }^{5}$, David Beddows ${ }^{6}$, Urška Rauter ${ }^{7}$, Stephanie Pilgaard $^{1,2}$, Manuel Dall'Osto ${ }^{8}$, Nina Gunde-Cimerman ${ }^{7}$, Andreas Massling ${ }^{4,5}$, Heike Wex $^{9}$}

${ }^{1}$ Stellar Astrophysics Centre, Department of Physics and Astronomy, Aarhus University, 8000 Aarhus, Denmark

${ }^{2}$ Department of Bioscience, Microbiology Section, Aarhus University, 8000 Aarhus, Denmark

${ }^{3}$ Department of Bioscience, Arctic Research Center, Aarhus University, 8000 Aarhus, Denmark

${ }^{4}$ iCLIMATE Aarhus University Interdisciplinary Centre for Climate Change, Aarhus University, Department of Environmental Science, 4000 Roskilde, Denmark

${ }^{5}$ Department of Environmental Science, Aarhus University, 4000 Roskilde, Denmark

${ }^{6}$ School of Geography, Earth and Environmental Sciences, University of Birmingham, B15 2TT Birmingham, UK

${ }^{7}$ Department of Biology, University of Ljubljana, 1000 Ljubljana, Slovenia

${ }^{8}$ Department of Marine Biology and Oceanography, Institute of Marine Sciences, 08003 Barcelona, Spain

${ }^{9}$ Leibniz Institute for Tropospheric Research, 04318 Leipzig, Germany

*Corresponding author: Tina Šantl-Temkiv, Aarhus University, Department of Bioscience, 116 Ny Munkegade, Aarhus, DK-8000, Phone number: 00458715 4337, email address: temkiv@phys.au.dk

Number of pages: 8

Figures: 3

Tables: 2 


\section{Methods}

\subsection{Sample collection with high-flow-rate impinger}

The samples were collected either into a high-salt sampling solution ${ }^{1}$ or into $1 \mathrm{x}$ PBS buffer (containing $0.137 \mathrm{M} \mathrm{NaCl}, 2.7 \mathrm{mM} \mathrm{KCl}, 4.29 \mathrm{mM} \mathrm{Na} 2 \mathrm{HPO}$, and $1.47 \mathrm{mM} \mathrm{KH} 2 \mathrm{PO} 4, \mathrm{pH} 7.2$, autoclaved three times for $3 \mathrm{~h}$ and $0.1 \mu \mathrm{m}$-filter-sterilized). The evaporated sampling liquid was replaced by autoclaved (three times for $3 \mathrm{~h})$, filtered $(0.1 \mu \mathrm{m}$ poresize, VacuCap 90 Devices, Pall Corporation, New York) MQ water. The impinger used for sampling into PBS buffer was modified by installing two heaters into the vortex chamber in order to prevent PBS to freeze. The PBS temperature was kept at $1-15^{\circ} \mathrm{C}$ with a temperature controller. Prior to use, the vortex chamber was cleaned under sterile conditions in a clean lab as described earlier ${ }^{2}$ and a blank was collected prior to transporting the chamber to the field. The samples were taken into the PBS buffer from Flygers hut (Figure 1C). Sampling into the high-salt solution using the high-flow-rate impinger was performed upwind of the Villum Research Station at three different sites from a platform $2 \mathrm{~m}$ above ground (Figure 1D). The samples were concentrated on Sterivex filters $(0.2 \mu \mathrm{m}$ pore size, SigmaAldrich). Two mL of RNA later solution was added to the filtered samples collected into the highsalt sampling solution, which were then stored at room temperature until DNA extraction. The cells collected into the PBS buffer were stored cooled $\left(\right.$ at $\left.4^{\circ} \mathrm{C}\right)$ until the analysis. The cells from these samples were suspended from the Sterivex filters into $3.5 \mathrm{~mL}$ of PBS and then used for cultivation and cell quantification by flow cytometry. The concentration of cells $\left(\mathrm{c}_{\text {cells }}\right)$ determined on two occasions by the high-flow-rate impinger and flow cytometry compared well with the $\mathrm{c}_{\text {cells }}$ determined by high-flow-rate filter sampling and microscopy counts considering the different methods used and the different timer resolution covered by the two methods (average $\mathrm{c}_{\text {cells }}$ of $1.1 \times$ $10^{4} \mathrm{~m}^{-3}$ (StN-PBS-1s and StN-PBS-2s ) and average $\mathrm{c}_{\text {cells }}$ of $2.6 \times 10^{4} \mathrm{~m}^{-3}(\mathrm{StN}-\mathrm{F}-4$ and StN-F-5)).

\subsection{Isolation of cultivable microorganisms and screening for ice-nucleation activity}

Bacterial and yeast strains were obtained by spreading $100 \mathrm{ul}$ of concentrated snowmelt and PBS sample on R2A medium (cultivation of bacteria $^{3}$ ) or DG18 medium supplemented with chloramphenicol (cultivation of yeast ${ }^{4}$ ). Triplicate media were grown at $4{ }^{\circ} \mathrm{C}$ and at $20^{\circ} \mathrm{C}$ for two weeks. The colonies were re-plated once observed on the plates and transferred three times or until pure cultures were obtained. All isolates were kept pure throughout this study.

Bacterial DNA was extracted from pure colonies as described previously ${ }^{5}$. The DNA extracts were amplified using primers Bac8f (5'-AGR GTT TGA TCC TGG CTC AG-3') and Bac1492R (5'-CGC CTA CCT TGT TAC GAC TT-3'), using either Red Taq polymerase (Sigma-Aldrich) or HotStar Polymerase (Qiagen) following the instructions of the manufacturer. The amplification program was as follows: a denaturation step of $5 \mathrm{~min}$ (RedTaq) or $10 \mathrm{~min}$ (Hotstar) at $95^{\circ} \mathrm{C}$ was followed by 25 cycles of denaturation at $94^{\circ} \mathrm{C}$ for $1 \mathrm{~min}$, annealing at $52^{\circ} \mathrm{C}$ for $1 \mathrm{~min}$ and elongation at $72^{\circ} \mathrm{C}$ for $1 \mathrm{~min}$. A final elongation step of $10 \mathrm{~min}$ at $72^{\circ} \mathrm{C}$ was performed. Once amplified, the PCR products were assessed by gel electrophoresis, using a 1.5\% agarose gel, and cleaned using GenElute PCR Cleanup Kit (Sigma-Aldrich) as per the manufacturer's protocol. The cleaned PCR products were then sequenced by Macrogen (Seoul, South Korea). The sequences were quality controlled and trimmed using Geneious version 8.1. The trimmed sequences were then run through Geneious' inbuilt BLAST function.

Isolates affiliating to Pseudomonas, Erwinia and Xanthomonas were selected and screened for the presence of the ice nucleation activity gene ${ }^{6}$ using the primers INA-3308F(5'-GGC GAT MGV AGC AAA CTS AC-3') and INA-3463R (5'-STG TAV CKT TTN CCG TCCCA-3'). The PCR master mix contained $12.5 \mu \mathrm{L}$ RedTaq polymerase, $1 \mu \mathrm{L}$ of each primer, $8.5 \mu \mathrm{L} \mathrm{dH} 2 \mathrm{O}$ and the template was $2 \mu \mathrm{L}$ DNA extract. The PCR program was as follows: A denaturation step at $95^{\circ} \mathrm{C}$ for 10 minutes followed by 25 cycles of denaturation at $95^{\circ} \mathrm{C}$ for $30 \mathrm{~s}$, annealing at $56^{\circ} \mathrm{C}$ for $30 \mathrm{~s}$ and 
elongation at $72^{\circ} \mathrm{C}$ for $30 \mathrm{~s}$. A final elongation step was performed at $72^{\circ} \mathrm{C}$ or $10 \mathrm{~min}$. The products were visualised using gel electrophoresis with a $2 \%$ agarose gel.

All yeasts and all bacterial isolates identified as Pseudomonas, Erwinia or Xanthomonas were screened for ice nucleation activity. Liquid bacterial cultures were grown in $\mathrm{R} 2$ medium at $20^{\circ} \mathrm{C}$ for 24 or $48 \mathrm{~h}$ on a shaker. The tubes were then transferred to $4^{\circ} \mathrm{C}$ for $24 \mathrm{~h}$ to induce the expression of the ice nucleation activity genes. Four replicates of $240 \mu \mathrm{L}$ for each culture were transferred to 96well microtiter plates. The microtiter plates were then placed into the climate chamber (MKT 115, Binder) at $-10^{\circ} \mathrm{C}$ for 100 minutes. Ice formation was assessed visually. If more than two out of four replicates were frozen after $100 \mathrm{~min}$, the strain was considered INA. Yeast cells were scraped off the DG18 medium and suspended in $2 \mathrm{~mL}$ of sterile PBS. After cold conditioning at $4^{\circ} \mathrm{C}$ for $>2 \mathrm{~h}$, yeasts were screened for ice nucleation activity at $-10^{\circ} \mathrm{C},-12^{\circ} \mathrm{C}$, and $-15^{\circ} \mathrm{C}$.

\subsection{SMPS and EDM data}

Since 2010 particle number size distributions in the submicrometer range $(9-900 \mathrm{~nm})$ have been measured continuously at VRS with a custom-built Scanning Mobility Particle Sizer (SMPS) system. Measurements from this instrument have been used in several previous studies ${ }^{7-10}$. The instrument is described in detail elsewhere ${ }^{7}$. In brief, the SMPS system samples ambient aerosols through a heated particle inlet with no addition aerosol drying, as transition from the cold ambient temperatures into the heated inside of the sample hut ensures sufficient drying. The SMPS utilizes a Vienna-type medium Differential Mobility Analyser (DMA) column with $1 \mathrm{~L} \mathrm{~min}^{-1}$ sample flow and $5 \mathrm{~L} \mathrm{~min}^{-1}$ sheath flow, and either a TSI model 3010 Condensational Particle Counter (CPC) or a TSI 3772 CPC. Instrument operating parameters, sheath- and sample flow, temperature and relative humidity are monitored and ensured to stay within limits. Inversion of measured raw data is performed off-line, with an algorithm according to previously outlined principles ${ }^{11}$. All inverted measurement data is visually inspected for faulty data or influence from nearby vehicles or other pollution sources. Measurements with faulty data or influence of local pollution are discarded. Measurements of mass concentration of particle smaller than $10 \mu \mathrm{m}$ (PM10) were made with an Environmental Dust Monitor (EDM) model 107E from GRIMM. Measurements from this instrument were available only during 1. Jan to 28. Apr 2016, making consistent correlation of PM10 with the concentration of INP impossible.

To get an estimate of PM10 concentration outside of the period where EDM measurements were available, measurements of PM10 were correlated with aerosol mass concentrations in the range of $400-900 \mathrm{~nm}$. This was done by transforming the SMPS particle number size distribution into the mass distribution (assumed particle density was $1.5 \mathrm{~g} \mathrm{~cm}^{-312}$ ) and subsequent integration of the particle mass distribution in the range of 400-900 $\mathrm{nm}$. The relationship was found significant using Pearson product-moment correlation $\left(\mathrm{R}^{2}=0.83, \mathrm{df}=2679, \mathrm{p}<0.001\right.$, Figure $\left.\mathrm{S} 1\right)$. A linear fit of EDM PM10 as a function of SMPS mass concentration in the range of 400-900 nm (MSMP) yielded: PM10 $=5.25 * \mathrm{M}_{\text {SMPS}}-0.02\left(\mathrm{R}^{2}=0.69\right)$. This allows us to use $\mathrm{M}_{\mathrm{SMPS}}$ as a proxy for PM10. However it is not certain that this correlation is also valid during summer periods, where submicrometer aerosol mass tends to decrease ${ }^{8}$, while PM10 likely is increased due to higher concentrations of wind-blown dust ${ }^{13}$. While this is not a critical parameter for this study, we include it for comparison with the bioaerosol concentrations. 


\section{Figures and Tables}
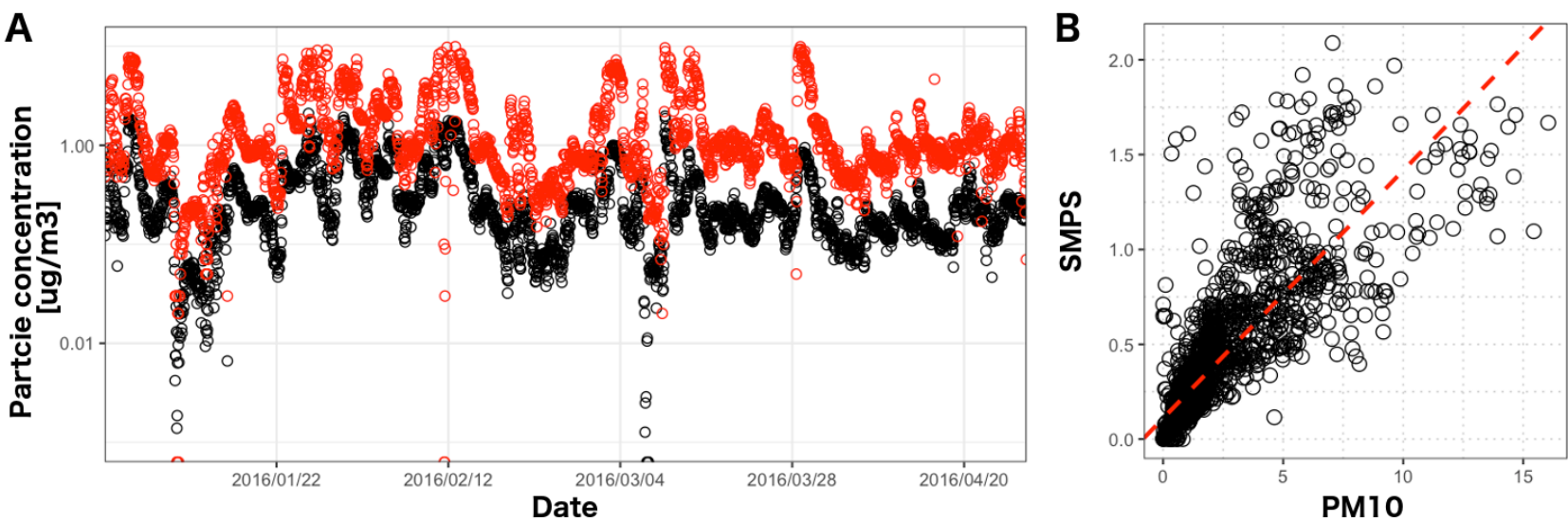

Figure S1: A - Plot showing the mass concentration of particles (averaged $1 / 2$ hourly) over time between Jan 2016 and April 2016. Integrated SMPS mass of the particles with diameters of 400-900 nm (black) and PM10 measured by EDM180 (GRIMM Aerosol) (red). B - Plot showing the relationship between integrated SMPS mass of the particles with diameters of 400-900 nm and the PM10 values. The relationship was found significant using Pearson product-moment correlation $\left(\mathrm{R}^{2}\right.$ $=0.83, \mathrm{df}=2679, \mathrm{p}<0.001)$.



Figure S2: A- Range of concentrations for airborne bacterial cells, 16S rRNA genes, and ice nucleating particles in spring and summer. B- Range of concentrations of wet-deposited bacterial cells, 16S rRNA, and ice nucleating particles in spring, all derived from snowfall. C- A fluorescent microscopy image showing airborne particles containing bacterial cells embedded into an EPS matrix. pINP-10 - cumulative proteinaceous INP active at $<-10^{\circ} \mathrm{C}$; pINP-20 $_{-}$- cumulative proteinaceous INP active at $<-20^{\circ} \mathrm{C}$. 

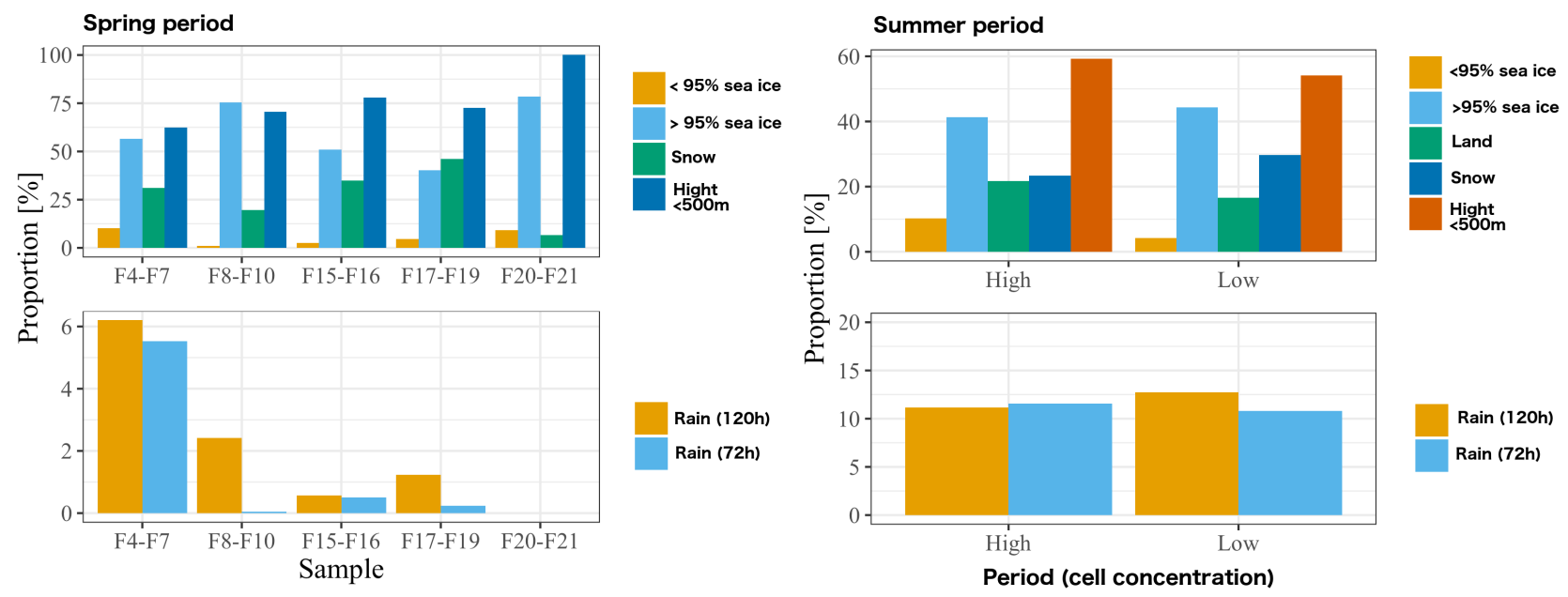

Figure S3: The proportion of time that the backward trajectories spend over regions with different sea-ice and snow coverage, bellow $500 \mathrm{~m}$ height and with rainfall. Rainfall is presented for both 3day and 5-day backward trajectories. The filter with high bioaerosol concentration in summer: F3, F4, F5 and F7; the filters with low concentration: F1 and F6. Detailed descriptions of the samples can be found in Table S1. 


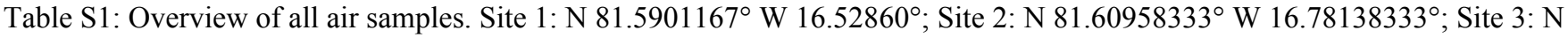
$81.6255167^{\circ} \mathrm{W} 16.72255^{\circ}$; Flygers hut: N $81.5816333^{\circ} \mathrm{W} 16.72255^{\circ}$.

Sample ID

StN-F-4

StN-F-5

StN-F-6

StN-F-7

StN-F-8

StN-F-9

StN-F-10

StN-F-15

StN-F-16

StN-F-17

StN-F-18

StN-F-19

StN-F-20

StN-F-21

StN-RNA-1-DNA Impinger 1

StN-RNA-2-DNA Impinger 2

StN-RNA-3-DNA Impinger 2

StN-RNA-4-DNA Impinger 1

StN-RNA-5-DNA Impinger 1

StN-RNA-6-DNA Impinger 3

StN-RNA-7-DNA Impinger 3

StN-RNA-8-DNA Impinger 3

StN-RNA-9-DNA Impinger 3

StN-RNA-10-DNA Impinger 3

StN-RNA-11-DNA Impinger 3

StN-RNA-12-DNA Impinger 3

StN-RNA-13-DNA Impinger 3

StN-RNA-14-DNA Impinger 3

StN-RNA-15-DNA Impinger 3

StN-RNA-16-DNA Impinger 3

StN-RNA-17-DNA Impinger 3

StN-RNA-18-DNA Impinger 3

StN-PBS-1s

Impinger $\mathrm{F}$

StN-PBS-2s

StN-PBS-3s

plygers hut 23/04/2015 18.20

R-16spr-Sample1

Impinger Flygers hut 25/04/2015 16.55

Filter

R-16spr-Sample3 Filter

R-16spr-Sample4 Filter

R-16spr-Sample5 Filter

R-16spr-Sample6 Filter

R-16spr-Sample7 Filter

R-16spr-Sample8 Filter

R-16spr-Sample9 Filter

R-16spr-Sample10 Filter

R-16spr-Sample11 Filter

R-16spr-Sample12 Filter

R-16spr-Sample13 Filter

R-16spr-Sample14 Filter

R-16sum-Sample 1 Filter

R-16sum-Sample 2 Filter

R-16sum-Sample 3 Filter

R-16sum-Sample 4 Filter

R-16sum-Sample 5 Filter

R-16sum-Sample 6 Filter

R-16sum-Sample 7 Filter

Flygers hut 24/04/2015 15.45

Flygers hut 25/04/2015 17.00

Flygers hut 27/04/2015 17.05

Flygers hut 29/04/2015 16.05

Flygers hut $01 / 05 / 2015 \quad 16.30$

Flygers hut $11 / 05 / 2015 \quad 10.00$

Flygers hut $12 / 05 / 2015 \quad 10.15$

Flygers hut 14/05/2015 10.15

Flygers hut 15/05/2015 10.10

Flygers hut 17/05/2015 10.10

Flygers hut 19/05/2015 10.10

Flygers hut 20/05/2015 10.20

$14 / 04 / 2015 \quad 11.15$

$16 / 04 / 2015 \quad 12.25$

$17 / 04 / 2015 \quad 16.00$

$18 / 04 / 2015 \quad 10.50$

$20 / 04 / 2015 \quad 08.35$

$21 / 04 / 2015 \quad 20.00$

$22 / 04 / 2015 \quad 14.10$

$23 / 04 / 2015 \quad 12.30$

$24 / 04 / 2015 \quad 14.55$

$25 / 04 / 2015 \quad 08.10$

$27 / 04 / 2015 \quad 11.10$

$30 / 04 / 2015 \quad 09.15$

$30 / 04 / 2015 \quad 14.20$

$30 / 04 / 2015 \quad 19.25$

$06 / 05 / 2015 \quad 16.40$

$08 / 05 / 2015 \quad 12.40$

$12 / 05 / 2015 \quad 17.15$

$14 / 05 / 2015 \quad 14.45$

Flygers hut 27/08/2016 14.25

Flygers hut 22/08/2016 00.30

Flygers hut 23/08/2016 20.05
Start date Start time End Date End time

Duration [h] Volume of air [m3]

$\begin{array}{llllll}\text { Flygers hut 21/04/2015 } & 15.00 & 22 / 04 / 2015 & 15.00 & 24,00 & 23,83\end{array}$

Flygers hut 22/04/2015 15.05

$24 / 04 / 2015 \quad 15.25$

48,42

48,08

$25 / 04 / 2015 \quad 16.20$

24,58

24,48

$27 / 04 / 2015 \quad 17.05$

48,00

48,10

$28 / 04 / 2015 \quad 16.05$

24,00

24,05

$01 / 05 / 2015 \quad 16.15$

48,17

33,96

$05 / 05 / 2015 \quad 10.15$

89,75

67,20

$12 / 05 / 2015 \quad 10.15$

24,25

24,74

$14 / 05 / 2015 \quad 10.15$

48,17

49,13

$15 / 05 / 2015 \quad 10.10$

23,92

24,40

$17 / 05 / 2015 \quad 10.10$

48,00

48,96

$19 / 05 / 2015 \quad 10.10$

48,00

48,96

$20 / 05 / 2015 \quad 10.20$

24,17

23,33

5,5

$14 / 04 / 2015 \quad 16.15$

$16 / 04 / 2015 \quad 17.25$

$17 / 04 / 2015 \quad 21.00$

$18 / 04 / 2015 \quad 15.50$

$20 / 04 / 2015 \quad 13.35$

$22 / 04 / 2015 \quad 00.10$

$22 / 04 / 2015 \quad 18.05$

$23 / 04 / 2015 \quad 17.20$

$24 / 04 / 2015 \quad 19.55$

$25 / 04 / 2015 \quad 13.05$

$27 / 04 / 2015 \quad 16.00$

$30 / 04 / 2015 \quad 14.15$

$30 / 04 / 2015 \quad 19.20$

$01 / 05 / 2015 \quad 00.25$

$06 / 05 / 2015 \quad 21.40$

$08 / 05 / 2015 \quad 19.20$

$12 / 05 / 2015 \quad 22.30$

$14 / 05 / 2015 \quad 20.00$

$21 / 04 / 2015 \quad 17.20$

$23 / 04 / 2015 \quad 23.10$

$25 / 04 / 2015 \quad 21.55$

$20 / 04 / 2016 \quad 20.30$

$22 / 04 / 2016 \quad 10.30$

$23 / 04 / 2016 \quad 11.30$

$24 / 04 / 2016 \quad 20.15$

$26 / 04 / 2016 \quad 12.15$

$27 / 04 / 2016 \quad 12.00$

$28 / 04 / 2016 \quad 11.45$

$29 / 04 / 2016 \quad 12.30$

$30 / 04 / 2016 \quad 14.15$

$01 / 05 / 2016 \quad 13.45$

$02 / 05 / 2016 \quad 11.15$

$03 / 05 / 2016 \quad 15.00$

$04 / 05 / 2016 \quad 11.15$

$05 / 05 / 2016 \quad 17.15$

$16 / 08 / 2016 \quad 20.35$

$18 / 08 / 2016 \quad 10.15$

$21 / 08 / 2016 \quad 20.40$

$23 / 08 / 2016 \quad 10.35$

$25 / 08 / 2016 \quad 10.15$

$26 / 08 / 2016 \quad 21.20$

$30 / 08 / 2016 \quad 17.30$
5,25

5,17

5

5

4,17

2,25

4,83

5

4,92

4,5

5

5

5

5

6,67

5

5,25

2,3

4,5

5

24,5

38

25

32,75

25

23,75

23,75

24,75

25,75

23,5

21,5

27,75

19,75

30

32,42

23,33

47,92

34,08

38,17

30,00

75,08
24,65

23,80

355,4

339,2

334,1

323,1

323,1

269,4

145,4

312,1

323,1

317,9

290,8

323, 1

323, 1

323,1

323,1

431,0

323,1

339,2

404, 0

779,3

323,1

28,518

44,232

29,1

38,121

29,1

27,645

27,645

28,809

29,973

27,354

25,026

32,301

22,989

34,92

30,73

22,12

45,42

32,31

36,18

28,44

71,18 
Table S2: Spearman's rank correlation coefficient and significance level for the correlation between airborne bioaeorosol concentrations, INP concentrations and meteorological parameters. Significant relationships are shown in red. Significance levels: ${ }^{*} \mathrm{p}<0.05 . \mathrm{R}-$ Pearson correlation coefficient, MSMPS - SMPS mass concentration, Temp - temperature, RH - relative humidity, VD - wind direction, VS - wind speed, RAD - radiation, 16S rRNA - 16S rRNA bacterial marker genes, INP10 - ice nucleating particles active at $\geq-10^{\circ} \mathrm{C}$.

\begin{tabular}{|c|c|c|c|c|c|c|c|c|c|c|}
\hline & \multicolumn{4}{|c|}{ Spring } & \multicolumn{6}{|c|}{ Summer } \\
\hline & \multicolumn{2}{|c|}{ 16S rRNA } & \multicolumn{2}{|c|}{ Cells } & \multicolumn{2}{|c|}{ 16S rRNA } & \multicolumn{2}{|c|}{ Cells } & \multicolumn{2}{|c|}{ INP10 } \\
\hline & $\mathrm{R}$ & $\mathrm{p}$ & $\mathrm{R}$ & $\mathrm{p}$ & $\mathrm{R}$ & $\mathrm{p}$ & $\mathrm{R}$ & $\mathrm{p}$ & $\mathrm{R}$ & $\mathrm{p}$ \\
\hline MSMPS & 0,28 & ns & 0,15 & $\mathrm{~ns}$ & 0,90 & ns & 0.4 & $\mathrm{~ns}$ & 0,70 & ns \\
\hline Temp & $-0,34$ & ns & $-0,38$ & ns & $-0,10$ & $\mathrm{~ns}$ & -0.8 & $\mathrm{~ns}$ & $-0,10$ & $\mathrm{~ns}$ \\
\hline RH & $-0,58$ & * & $-0,31$ & $\mathrm{~ns}$ & 0,30 & ns & 0.6 & $\mathrm{~ns}$ & 0,30 & ns \\
\hline VD & 0,19 & ns & $-0,07$ & ns & $-0,30$ & ns & 0.4 & $\mathrm{~ns}$ & $-0,30$ & ns \\
\hline VS (Mean) & 0,65 & * & $-0,32$ & ns & 0,00 & ns & 0.4 & ns & 0,00 & ns \\
\hline VS (Max) & 0,59 & * & $-0,34$ & $\mathrm{~ns}$ & 0,00 & ns & 0.4 & $\mathrm{~ns}$ & 0,00 & ns \\
\hline RAD & $-0,17$ & ns & $-0,05$ & ns & $-0,70$ & ns & -1 & $\mathrm{~ns}$ & $-0,70$ & ns \\
\hline Pressure & $-0,63$ & $*$ & $-0,12$ & ns & $-0,50$ & $\mathrm{~ns}$ & 0.8 & $\mathrm{~ns}$ & $-0,50$ & $\mathrm{~ns}$ \\
\hline
\end{tabular}




\section{References}

(1) Lever, M. A.; Torti, A.; Eickenbusch, P.; Michaud, A. B.; Šantl-Temkiv, T.; Jørgensen, B. B. A Modular Method for the Extraction of DNA and RNA, and the Separation of DNA Pools from Diverse Environmental Sample Types. Front. Microbiol. 2015, 6 (MAY) DOI: 10.3389/fmicb.2015.00476.

(2) Šantl-Temkiv, T.; Amato, P.; Gosewinkel, U.; Thyrhaug, R.; Charton, A.; Chicot, B.; Finster, K. W.; Bratbak, G.; Löndahl, J. High-Flow-Rate Impinger for the Study of Concentration, Viability, Metabolic Activity, and Ice-Nucleation Activity of Airborne Bacteria. Environ. Sci. Technol. 2017, 51 (19), 11224-11234 DOI: 10.1021/acs.est.7b01480.

(3) Reasoner, D. J.; Geldreich, E. E. A New Medium for the Enumeration and Subculture of Bacteria from Potable Water. Appl. Environ. Microbiol. 1985, 49 (1), 1-7 DOI: 10.1016/s0016-7037(99)00322-1.

(4) Hocking, A. D.; Pitt, J. I. Dichloran-Glycerol Medium for Enumeration of Xerophilic Fungi from Low-Moisture Foods. Appl. Environ. Microbiol. 1980, 39 (3), 488-492 DOI: 10.1088/0965-0393/24/3/035001.

(5) Temkiv, T. Š.; Finster, K.; Hansen, B. M.; Nielsen, N. W.; Karlson, U. G. The Microbial Diversity of a Storm Cloud as Assessed by Hailstones. FEMS Microbiol. Ecol. 2012 DOI: 10.1111/j.1574-6941.2012.01402.x.

(6) Hill, T. C. J.; Moffett, B. F.; Demott, P. J.; Georgakopoulos, D. G.; Stump, W. L.; Franc, G. D. Measurement of Ice Nucleation-Active Bacteria on Plants and in Precipitation by Quantitative PCR. Appl. Environ. Microbiol. 2014, 80 (4), 1256-1267 DOI: 10.1128/AEM.02967-13.

(7) Nguyen, Q. T.; Glasius, M.; Sørensen, L. L.; Jensen, B.; Skov, H.; Birmili, W.; Wiedensohler, A.; Kristensson, A.; Nøjgaard, J. K.; Massling, A. Seasonal Variation of Atmospheric Particle Number Concentrations, New Particle Formation and Atmospheric Oxidation Capacity at the High Arctic Site Villum Research Station, Station Nord. Atmos. Chem. Phys. 2016, 16 (17), 11319-11336 DOI: 10.5194/acp-16-11319-2016.

(8) Freud, E.; Krejci, R.; Tunved, P.; Leaitch, R.; Nguyen, Q. T.; Massling, A.; Skov, H.; Barrie, L. Pan-Arctic Aerosol Number Size Distributions: Seasonality and Transport Patterns. Atmos. Chem. Phys. 2017, 17 (13), 8101-8128 DOI: 10.5194/acp-17-8101-2017.

(9) Lange, R.; Dall'Osto, M.; Skov, H.; Nøjgaard, J. K.; Nielsen, I. E.; Beddows, D. C. S.; Simo, R.; Harrison, R. M.; Massling, A. Characterization of Distinct Arctic Aerosol Accumulation Modes and Their Sources. Atmos. Environ. 2018, 183 (March), 1-10 DOI:

10.1016/j.atmosenv.2018.03.060.

(10) Dalĺosto, M.; Geels, C.; Beddows, D. C. S.; Boertmann, D.; Lange, R.; Nøjgaard, J. K.; Harrison, R. M.; Simo, R.; Skov, H.; Massling, A. Regions of Open Water and Melting Sea Ice Drive New Particle Formation in North East Greenland. Sci. Rep. 2018, 8 (1), 1-10 DOI: 10.1038/s41598-018-24426-8.

(11) Pfeifer, S.; Birmili, W.; Schladitz, A.; Müller, T.; Nowak, A.; Wiedensohler, A. A Fast and Easy-to-Implement Inversion Algorithm for Mobility Particle Size Spectrometers Considering Particle Number Size Distribution Information Outside of the Detection Range. Atmos. Meas. Tech. 2014, 7 (1), 95-105 DOI: 10.5194/amt-7-95-2014.

(12) Nguyen, Q. T.; Glasius, M.; Sørensen, L. L.; Jensen, B.; Skov, H.; Birmili, W.; Wiedensohler, A.; Kristensson, A.; Nøjgaard, J. K.; Massling, A. Seasonal Variation of Atmospheric Particle Number Concentrations, New Particle Formation and Atmospheric Oxidation Capacity at the High Arctic Site Villum Research Station, Station Nord. Atmos. Chem. Phys. 2016, 16 (17), 11319-11336 DOI: 10.5194/acp-16-11319-2016.

(13) Myhre, C. L. Monitoring of Greenhouse Gases and Aerosols at Svalbard and Birkenes in 2014 Annual Report Project Manager for the Contractor; 2015. 